\title{
A comparison of vineyard soil temperatures and growing conditions in localities in southern Finland, Estonia, and Latvia
}

\begin{abstract}
In recent decades, the cultivation of grapevines for wine production has been undertaken in the Baltic states and Scandinavia. Its success depends, among other factors, on the climate, the length of the growing season, the soil, and soil temperature. This study measured vineyard soil temperatures in four localities, in Southern Finland, Estonia, and Latvia, from November 2009 to December 2010. During the coldest months of January, February and March, soil temperatures at depths of $25 \mathrm{~cm}$ and $45 \mathrm{~cm}$ were $0^{\circ} \mathrm{C}$ or slightly higher, so the roots of the vines did not freeze, nor did the soil temperature prevent grapevines from surviving the winter. In April, in the Southern Finnish locality (Tuusula), the average temperature of the soil was 3.4 to $4.1^{\circ} \mathrm{C}$ lower than in the Estonian and Latvian locations. This difference grew smaller during the growing season, but remained statistically significant. Soil temperatures in the four localities included in the study reached those of Zlín (Moravia), in the Czech Republic 10-12 days later. It can be concluded from the results that soil temperature differences correspond to differences in growing season, especially in the spring.
\end{abstract}

Keywords: grapevine, Nordic viticulture, soil temperature, growing season
Volume 8 Issue 2 - 2018

\author{
J Karvonen,' J Kivistik ${ }^{2}$ \\ 'Department of Agricultural Sciences, Faculty of Agriculture and \\ Forestry, University of Helsinki, Finland \\ ${ }^{2}$ Räpina School of Horticulture Estonia
}

Correspondence: J Karvonen, Department of Agricultural Sciences, Faculty of Agriculture and Forestry, University of Helsinki, PO. Box 28, 00014 Helsinki, Finland,

Email: juha.i.karvonen@helsinki.fi

Received: December 27, 2017 | Published: March 12, 2018

\section{Introduction}

The outdoor cultivation of grapevines is expanding northwards. Its success depends on the temperature of the climate, the length of the growing season, and the temperature of the soil. The growing seasons of areas at the same altitude lengthen, and the soil grows warm earlier, as one moves south and west. This has been confirmed in studies by Värnik ${ }^{1} \&$ Koivisto, ${ }^{2}$ in which the Estonian $\left(59^{\circ} \mathrm{N}\right)$, growing season is 3-4 days longer than in southernmost Finland $\left(60^{\circ} \mathrm{N}\right)$. In Latvia $\left(56^{\circ} \mathrm{N}\right)$, the growing season is $10-11$ days, and in Central Europe $\left(50^{\circ} \mathrm{N}\right) 3-4$ weeks longer than in Southern Finland. The length of the growing season is affected by the climate, air temperature, soil quality, and soil temperature. Air and soil temperatures are highly interdependent (Yli-Halla\&Mokma. ${ }^{3}$ Mokma\&Sprecher ${ }^{4}$ found that the mean annual ground temperature is $1{ }^{\circ} \mathrm{C}$ higher than the mean air temperature for a year. As with climate, soils are classified into different categories. According to the U.S. Soil Taxonomy system Soil Survey Staff, ${ }^{5}$ Finnish mineral agricultural soil belongs primarily to the 'cryic' temperature regime.

The land is suitable for agricultural production, but its coldness limits the cultivation of crops such as maize and grapevines. The area south of the 'cryic' regime belongs to the 'frigid' temperature regime, which includes lands south of the Gulf of Finland, as far as the latitude of Skåne. Of the Central European countries, a large proportion belong to a warmer 'mesic' soil temperature regime, but the mountainous areas used there for farming and grapevine cultivation also belong to the 'frigid' soil temperature regime. Yli-Halla et al. ${ }^{6}$ considered whether the southernmost Finnish farmland belongs to the 'cryic' or 'frigid' regime and decided, by comparing Swedish and Finnish crop yields, that it still belongs within the 'cryic' regime. The growing conditions can also be examined on the basis of vegetation zone division. According to the division of European vegetation zones, Finland's western and southern coasts belong to the temperate hemiboreal zone of deciduous and mixed forests $\left(60-55^{\circ} \mathrm{N}\right)$. Its climate is cooler than that of the temperate zone and the growing seasons are a little shorter. Southern Sweden, Southern Norway, and the Baltic states also belong to the hemiboreal zone Peel. ${ }^{7}$ To its south is mainly deciduous forest and the temperate zone of broad-leaved deciduous trees, which is a traditional vine-growing area. The aim of this study was to investigate the extend to which vineyard soil temperatures in Southern Finland (Tuusula $60^{\circ} 24^{\prime} 10^{\prime \prime} \mathrm{N}, 25^{\circ} 01^{\prime} 45^{\prime \prime} \mathrm{E}$ ), Estonia (Pärnu $58^{\circ} 23^{\prime} \mathrm{N}$, $24^{\circ} 30^{\prime} \mathrm{E}$ and Räpina $58^{\circ} 05^{\prime} 51^{\prime \prime} \mathrm{N}, 27^{\circ} 27^{\prime} 54^{\prime \prime} \mathrm{E}$ ) and Latvia (Tervete $56^{\circ} 29^{\prime} \mathrm{N}, 23^{\circ} 25^{\prime} \mathrm{E}$ ) differ from each other when measured at the same time, and how closely they correspond to the soil temperature regimes of the Soil Taxonomy system. In addition, the study was aimed to evaluate the time period within which the same soil temperature, as in the vineyards of the Moravian wine region of the Czech Republic $\left(49^{\circ} 13^{\prime} 59^{\prime}\right.$ 'N, $17^{\circ} 40^{\prime} 01^{\prime}$ 'E), would be achieved in southern Finland, Estonia and Latvia, and how great the difference might be between the growing seasons.

\section{Materials and methods}

Soil temperatures were recorded using temperature and humidity loggers (Thermo Button 21G, Proges-Plus, France) at the same time in Tuusula, Räpina, Pärnu and Tervete: from December 2009 to November 2010 in Tuusula (Southern Finland), Räpina. (Estonia), Pärnu (Estonia) and Tervete (Latvia), and from May 4 to 9 in Zlín in the Czech Republic. The loggers measured soil temperatures at one minute intervals at depths of $25 \mathrm{~cm}$ and $45 \mathrm{~cm}$, which they recorded to memory, from which the data were transferred for analysis to the Department of Applied Biology, Faculty of Agriculture and Forestry, University of Helsinki, Finland. At Zlín, soil temperature was measured using temperature sensors $25 \mathrm{~cm}$ below the surface (Waterproof In-Out Door Max-Min Thermometer with Hygrometer, Shenzhen Hong Tong Yuan Technology Ltd., Shenzhen, China), from which the maximum and minimum temperatures were saved to the thermometer memory during the period 4-9 May 2010. Mean soil temperatures $(\bar{x})$ and standard deviations (SD) were calculated using 
an Excel spreadsheet. Two tailed TTEST (Student's t-test) were used to estimate statistical significance $(\mathrm{P}=0.05-0.001)$.

\section{Results and discussion}

At Tuusula, Räpina, and Pärnu, soil temperatures at a depth of $25 \mathrm{~cm}$ remained at or above zero all winter. At this depth, ground temperatures at the locations, in degrees Celsius, differed only slightly until March, but the t-values were large and the differences statistically significant $(\mathrm{P}<0.05-0.001)$. From April to August mean temperatures at $25 \mathrm{~cm}$ at Räpina and Pärnu were $3.4-3.5^{\circ} \mathrm{C}$ higher than soil temperatures at Tuusula. This difference was considerable. The lowest temperatures were recorded in January, February and March, and the highest in July. From September to November, the differences between the localities decreased, but the mean soil temperature at Tuusula was still significantly lower than at other locations (Table 1). Mean soil temperatures in the summer months (June, July and August) were slightly lower at a depth of $45 \mathrm{~cm}$ than at $25 \mathrm{~cm}$ (Table 2), and in the winter months of January, February and March mean temperatures at $45 \mathrm{~cm}$ remained at least $0.5^{\circ} \mathrm{C}$ higher than at $25 \mathrm{~cm}$ (Table 3). The marine climate of Pärnu may have kept the end of year temperatures higher than at other localities. Räpina, on the other hand, has a continental climate, with colder autumns and winters. Soil temperature differences for the winter months were statistically significant $(\mathrm{P}<0.001)$. On this basis, the ground provides a good insulator against heat and cold. Forest fire studies have shown that even if the air temperature in a fire rises $815^{\circ} \mathrm{C}$ in 15 seconds, the temperature at a depth of $12 \mathrm{~cm}$ is $41^{\circ} \mathrm{C}$ and at $25 \mathrm{~cm}$ it is $35^{\circ} \mathrm{C}$ Bernanke. $^{8}$

Table I Vineyard soil temperature changes at a depth of $25 \mathrm{~cm}$ in 2009-2010

\begin{tabular}{llllllllllll}
\hline & Tuusula & & Räpina & \multicolumn{3}{c}{ Tuusula/Räpina } & \multicolumn{2}{c}{ Pärnu } & \multicolumn{3}{c}{ Tuusula/Pärnu } \\
\hline & ${ }^{\circ} \mathrm{C}$ & $\mathrm{n}$ & ${ }^{\circ} \mathrm{C}$ & $\mathrm{n}$ & $\mathrm{t}$ & $\mathrm{P}$ & ${ }^{\circ} \mathrm{C}$ & $\mathrm{n}$ & $\mathrm{t}$ & $\mathrm{P}$ \\
$\mathrm{Dec}$ & $1.6 \pm 0.9$ & 124 & $1.5 \pm 1.7$ & 124 & 0.058 & $>0.05$ & $0.5 \pm 0.1$ & 62 & 13.414 & $<0,001$ \\
Jan & $0.5 \pm 0.0$ & 124 & $0.0 \pm 0.0$ & 124 & - & - & $1.0 \pm 0.1$ & 124 & 55.679 & $<0.001$ \\
$\mathrm{Feb}$ & $0.3 \pm 0.2$ & 112 & $0.0 \pm 0.0$ & 112 & 15.873 & $<0.001$ & $0.0 \pm 0.0$ & 112 & 15.873 & $<0.001$ \\
Mar & $0.2 \pm 0.3$ & 124 & $0.0 \pm 0.0$ & 124 & 7.722 & $<0.001$ & $1.0 \pm 0.1$ & 124 & 28.268 & $<0.001$ \\
Apr & $1.7 \pm 1.7$ & 120 & $5.2 \pm 2.2$ & 120 & 13.834 & $<0.001$ & $5.1 \pm 1.3$ & 120 & 17.347 & $<0.001$ \\
May & $9.8 \pm 3.1$ & 124 & $12.9 \pm 3.4$ & 124 & 10.432 & $<0.001$ & $10.9 \pm 3.2$ & 124 & 2.794 & $<0.01$ \\
Jun & $13.2 \pm 0.9$ & 120 & $15.6 \pm 0.9$ & 120 & 20.69 & $<0.001$ & $13.6 \pm 1.1$ & 120 & 2.985 & $<0.01$ \\
Jul & $18.7 \pm 1.5$ & 124 & $20.6 \pm 1.5$ & 124 & 10 & $<0.001$ & $19.1 \pm 1.6$ & 124 & 2.174 & $<0.05$ \\
Aug & $17.5 \pm 2.0$ & 124 & $19.0 \pm 2.3$ & 124 & 5.494 & $<0.001$ & $17.7 \pm 1.9$ & 124 & 0.806 & $>0.05$ \\
Sep & $12.1 \pm 1.2$ & 120 & $12.6 \pm 1.1$ & 120 & 0.415 & $>0.05$ & $12.4 \pm 1.1$ & 120 & 2.113 & $<0.05$ \\
Oct & $6.1 \pm 1.8$ & 124 & $6.2 \pm 1.7$ & 124 & 0.45 & $>0.05$ & $6.6 \pm 1.1$ & 124 & 2.762 & $<0.01$ \\
\hline Nov & $4.1 \pm 1.4$ & 103 & $4.7 \pm 0.9$ & 83 & 3.55 & $<0.001$ & $6.3 \pm 3.1$ & 29 & 3.667 & $<0.01$ \\
\hline
\end{tabular}

Table 2 Vineyard soil temperature changes at a depth of $45 \mathrm{~cm}$ in $2009-2010$

\begin{tabular}{|c|c|c|c|c|c|c|c|c|c|c|}
\hline & \multicolumn{2}{|l|}{ Tuusula } & \multicolumn{2}{|l|}{ Räpina } & \multicolumn{2}{|c|}{ Tuusula/Räpina } & \multicolumn{2}{|l|}{ Pärnu } & \multicolumn{2}{|c|}{ Tuusula/Pärnu } \\
\hline & ${ }^{\circ} \mathrm{C}$ & $\mathrm{n}$ & ${ }^{\circ} \mathrm{C}$ & $\mathrm{n}$ & $\mathrm{t}$ & $P$ & ${ }^{\circ} \mathrm{C}$ & $\mathrm{n}$ & $\mathrm{t}$ & $P$ \\
\hline Dec & $1.6 \pm 0.9$ & 124 & $1.5 \pm 1.7$ & 124 & 0.058 & $>0.05$ & $0.5 \pm 0.1$ & 62 & $13.4 \mid 4$ & $<0,001$ \\
\hline Jan & $0.5 \pm 0.0$ & 124 & $0.0 \pm 0.0$ & 124 & - & - & $1.0 \pm 0.1$ & 124 & 55.679 & $<0.001$ \\
\hline Feb & $0.3 \pm 0.2$ & 112 & $0.0 \pm 0.0$ & 112 & 15.873 & $<0.001$ & $0.0 \pm 0.0$ & 112 & 15.873 & $<0.001$ \\
\hline Mar & $0.2 \pm 0.3$ & 124 & $0.0 \pm 0.0$ & 124 & 7.722 & $<0.001$ & $1.0 \pm 0.1$ & 124 & 28.268 & $<0.001$ \\
\hline Apr & $1.7 \pm 1.7$ & 120 & $5.2 \pm 2.2$ & 120 & 13.834 & $<0.001$ & $5.1 \pm 1.3$ & 120 & 17.347 & $<0.001$ \\
\hline May & $9.8 \pm 3.1$ & 124 & $12.9 \pm 3.4$ & 124 & 10.432 & $<0.001$ & $10.9 \pm 3.2$ & 124 & 2.794 & $<0.01$ \\
\hline Jun & $13.2 \pm 0.9$ & 120 & $15.6 \pm 0.9$ & 120 & 20.69 & $<0.001$ & $13.6 \pm 1.1$ & 120 & 2.985 & $<0.01$ \\
\hline Jul & $18.7 \pm 1.5$ & 124 & $20.6 \pm 1.5$ & 124 & 10 & $<0.001$ & $19.1 \pm 1.6$ & 124 & 2.174 & $<0.05$ \\
\hline Aug & $17.5 \pm 2.0$ & 124 & $19.0 \pm 2.3$ & 124 & 5.494 & $<0.001$ & $17.7 \pm 1.9$ & 124 & 0.806 & $>0.05$ \\
\hline Sep & $12.1 \pm 1.2$ & 120 & $12.6 \pm 1.1$ & 120 & 0.415 & $>0.05$ & $12.4 \pm 1.1$ & 120 & 2.113 & $<0.05$ \\
\hline Oct & $6.1 \pm 1.8$ & 124 & $6.2 \pm 1.7$ & 124 & 0.45 & $>0.05$ & $6.6 \pm 1.1$ & 124 & 2.762 & $<0.01$ \\
\hline Nov & $4.1 \pm 1.4$ & 103 & $4.7 \pm 0.9$ & 83 & 3.55 & $<0.001$ & $6.3 \pm 3.1$ & 29 & 3.667 & $<0.01$ \\
\hline
\end{tabular}


Table 3 Soil temperature differences between 25 and $45 \mathrm{~cm}$ depths for the three coldest months

\begin{tabular}{lllllll}
\hline Depth & $\mathbf{2 5} \mathbf{~ c m}$ & & $\mathbf{4 5} \mathbf{~ c m}$ & \multicolumn{3}{l}{$\begin{array}{l}\text { Statistical } \\
\text { significance }\end{array}$} \\
\hline $\begin{array}{l}\text { Temperature } \\
\text { Tuusula }\end{array}$ & ${ }^{\circ} \mathrm{C}$ & $\mathrm{n}$ & ${ }^{\circ} \mathrm{C}$ & $\mathrm{n}$ & $\mathrm{t}$ & $\mathrm{P}$ \\
Jan & $0.5 \pm 0.0$ & 124 & $1,4 \pm 0.2$ & 123 & 50.11114 & $<0.00 \mathrm{I}$ \\
Feb & $0.3 \pm 0.2$ & 112 & $1,0 \pm 0.0$ & 111 & 37.03703 & \\
Mar & $0.2 \pm 0.3$ & 124 & $1,0 \pm 0.0$ & 123 & 29.73977 & \\
Räpina & & & & & & \\
Jan & $0.0 \pm 0.0$ & 124 & $1,4 \pm 0.2$ & 123 & 77.7777 & $<0.001$ \\
Feb & $0.0 \pm 0.0$ & 112 & $1.0 \pm 0.0$ & 111 & & \\
\hline Mar & $0.0 \pm 0.0$ & 124 & $1.0 \pm 0.0$ & 123 & & \\
\hline
\end{tabular}

In the European boreal belt, at latitudes 60-63, the soil frost layer does not extend more than $40 \mathrm{~cm}$ below the surface Karvonen, ${ }^{9}$ so most plants can survive there. The effect of the Gulf Stream means that in Finland and elsewhere in Northern Europe it is possible to cultivate plants that, in North America, are grown at latitudes 50-60 Seager. ${ }^{10}$ In this study also, the soil temperature was maintained throughout the winter at zero degrees Celsius or above at depths of $25 \mathrm{~cm}$ and 45 $\mathrm{cm}$. On this basis, soil temperature does not restrict the cultivation of suitable grapevine varieties in these areas. However, the short growing season and late spring mean that not all European grapevines can be made productive using outdoor cultivation. In southern Finland, planting depths of $40-45 \mathrm{~cm}$ can be considered safe for grapevines in normal winters. In addition, a thick layer of snow reduces the danger of frost damage to the vines, as the research of Zhang et al. ${ }^{11}$ has shown. At this depth, the ground temperature in April is already so high $\left(5-7^{\circ} \mathrm{C}\right)$ that the liquid circulation of the grapevines begins, at Räpina, Pärnu, and Tervete, at latest in the first half of the month and at Tuusula in the second half of the month. Yli-Halla \& Mokma $^{3}$ found soil temperatures averaging $9.3^{\circ} \mathrm{C}$ from a depth of $50 \mathrm{~cm}$ at Jokioinen, Southern Finland $\left(60^{\circ} 49^{\prime} \mathrm{N}, 23^{\circ} 30^{\prime} \mathrm{E}\right)$, and $6.4^{\circ} \mathrm{C}$ from the same depth at Anjala $\left(60^{\circ} 41^{\prime} \mathrm{N}\right)$. They found mean soil temperatures of $0-8^{\circ} \mathrm{C}$ for the whole of Finland Yli-Halla \& Mokma. ${ }^{6}$ These studies show that soil temperature differences may be considerable even in locations at the same latitude, but temperature differences are particularly large between the northernmost parts of Lapland and southern Finland. The annual mean value of soil temperatures at Räpina, at a depth of $45 \mathrm{~cm}$, was $1.4^{\circ} \mathrm{C}$ higher than at Tuusula (Table 4). The north-south distance between the localities was $250 \mathrm{~km}\left(2.4^{\circ}\right.$ of latitude). Compared with the studies of Yli-Halla \& Mokma, ${ }^{3}$ the soil temperature difference between Tuusula and Räpina was lower than between Jokioinen and Anjala, at the same latitude. It can be concluded that the success of the grapevine is affected, not only by the north-south or eastwest geographical situation of the growth location, but also by the thermal conditions of the soil and the local climate. Although air and soil temperatures are strongly interdependent, there is a delay in the reaction of the land to rapid changes in air temperature. In contrast, a longer period of climate warming or cooling does raise or lower the soil temperature. Table 5 compares May soil temperatures from the

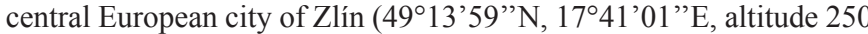
$\mathrm{m})$, with three research localities. Zlín belongs to the Moravian winegrowing region in the Czech Republic. There, the soil temperature for 4-9 May was $13.0 \pm 0.8^{\circ} \mathrm{C}$. At the same time, the soil temperatures at Tuusula, Räpina and Pärnu were half of that, and they reached the Zlín soil temperatures only 10-12 days later. There appears to be a connection between the soil's storage of heat and the length of the growing season. In this study, soil temperatures in the southernmost location, Tervete, during the months of the growing season and throughout the year, were higher than in the northern locations; in other words, soil temperature rose and the growing season became longer as one moved south. According to Rötzer \& Chmielewski, ${ }^{12}$ the growing season is extended 2.4 days $100 \mathrm{~km}^{-1}$ moving from north to south, and 0.7 days $100 \mathrm{~km}^{-1}$ moving from east to west. On this basis, the growing seasons in Pärnu and Räpina should be 5-6 days longer and in Tervete 10-11 days longer than in Tuusula. Värnik ${ }^{1} \&$ Koivisto $^{2}$ came to a similar conclusion.

Table4 Soil temperature differences at depths of 25 and $45 \mathrm{~cm}$ in 2010

\begin{tabular}{llllllll}
\hline Depth & $\mathbf{2 5} \mathbf{~ c m}$ & & $\mathbf{4 5} \mathbf{~ c m}$ & & \multicolumn{2}{c}{$\begin{array}{l}\text { Statistical } \\
\text { significance }\end{array}$} \\
\hline Temperature & ${ }^{\circ} \mathrm{C}$ & $\mathrm{n}$ & ${ }^{\circ} \mathrm{C}$ & $\mathrm{n}$ & $\mathrm{t}$ & $\mathrm{P}$ \\
Tuusula & $7.2 \pm 6.8$ & $\mid 463$ & $7.4 \pm 6.3$ & $\mid 460$ & $0.825 \mathrm{I}$ & $>0.05$ \\
\hline Räpinä & $8.2 \pm 7.5$ & $\mathrm{I} 463$ & $8.8 \pm 6.9$ & $\mid 463$ & 2.2556 & $<0.0 \mathrm{I}$
\end{tabular}

Table 5 Soil temperature differences at a depth of $25 \mathrm{~cm}$ by locality

\begin{tabular}{lllll}
\hline Locality & $\begin{array}{l}\text { 4-9 May } \\
\text { temperature }\end{array}$ & $\mathbf{n}$ & $\begin{array}{l}\text { Temperature } \\
\mathbf{1 3 . 0} \pm 0.8\end{array}$ & $\begin{array}{l}\text { Difference } \\
\text { in days }\end{array}$ \\
\hline Zlin & ${ }^{\circ} \mathrm{C}$ & & ${ }^{\circ} \mathrm{C}$ & \\
Tuusula & $6.0 \pm 0.5$ & 6 & $4-9$ May & - \\
Räpinä & $6.0 \pm 0.5$ & 6 & $16-21$ May & 12 \\
\hline Pärnu & $7.0 \pm 0.5$ & 6 & $16-21$ May & 12 \\
\hline
\end{tabular}

\section{Conclusion}

The soil temperatures at the Tuusula vineyard in southern Finland, at both $25 \mathrm{~cm}$ and $45 \mathrm{~cm}$ depth, were lower than at Räpina and Pärnu in Estonia, and at Tervete in Latvia, in the winter of 2009-2010. The mean soil temperature at Tuusula in April was $3.4-4.1^{\circ} \mathrm{C}$ lower than at Räpina, Pärnu and Tervete, showing that growing seasons in southern Finland and the Baltic states differ most in the spring. Thereafter, the differences were small, although still statistically significant. The soil temperature at Tuusula still fits the lower 'cryic' temperature regime for arable land while Räpina, Pärnuand Tervete fit the warmer 'frigid' temperature regime; however, some areas in the southernmost part of Finland might also be termed 'frigid'. In May, soil temperatures in Tuusula, Räpina and Pärnu were $6-7^{\circ} \mathrm{C}$ lower than in Zlín, in the Czech Republic, while the same soil temperature was not reached, in the former locations, until 10-12 days later. This also corresponds to differences between the spring growing seasons. The longer growing season with a long day, higher soil and air temperature leads to higher crop production. New crop species and varieties as maize, sweet potato, peanut, soybean, wild rice and grapevine will spread from South and Central Europe to northern Europe and the Baltic sea region. The generally believed negative effects are an increase in the need for plant protection, nutrient leaching and reduction of soil humus content, water shortage and extreme weather events. These weather phenomena lead to lower harvestable yields, higher yield variability and a reduction in suitable areas for traditional crops as grapevine in the Mediterranean region. According to Olesen \& Bindi ${ }^{13}$ the effects of climate change may reinforce the current trends 
of intensification of agriculture in northern and western Europe and intensification in the Mediterranean and south eastern parts of Europe and these conclusions have not changed so far.

\section{Acknowledgement}

We thank viticulturists Raimo Saar, Pärnu, Estonia and Edgars Zihmanis, Tervetes region, Latvia for soil temperature measurements.

\section{Conflict of interest}

None.

\section{References}

1. Värnik R. Efficiency of Strawberry cultivation in Estonia. Dissertationes Rerum Oeconomicarum Universitatis Agricuilturea Estoniae, 2001; pp.132-133.

2. Koivisto A. Competitive Advantages of Strawberry Growing in Estonia and Finland. MTT Economic Research, Agri food Research No 91, Finland;2005;1-13.

3. Yli-Halla M, Mokma DL. Soil temperature regimes in Finland. Agric Food Sci. 1998;7(4);507-512.

4. Mokma D, Sprecher SW. How frigid is frigid? Soil Survey Horizons. $1995 ; 36,71-76$.
5. Soil Taxonomy. The $2^{\text {nd }}$ ed. United States Department of Agriculture. Agricultural handbooks no:436; 1999; pp.112-113.

6. Yli-Halla M, Mokma D L, Starr E. Criteria for frigid and cryic temperature regimes. Soil Survey Horizons 2001;42(1);11-18.

7. Peel MC, Finlayson BL, McMahon TA. Updated world map of theKöppenGeiger climate classification. Hydrol Earth Syst Sci. 2007;11;1633-1644.

8. Bernanke J. 24 hours After Asteroid Impact. National Geographic Explorer. 2009.

9. Karvonen J. Soil temperature and grapevine growth in Finland. Master's Thesis. Department of Applied Biology and Department of Applied Chemistry and Microbiology. University of Helsinki. 2008;21-28.

10. Seager R. The Source of Europe's Mild Climate. American Scientist. 2006.

11. Zhang Y, Ping J, Wang W, et al. Comparison of different soil-burry methods on the over-wintering of wine grape cultivars in Ningxi Autonomous Region. J Fruit Sci. 2007;04;1

12. Rötzer T, Chemielewski FM. Phenological Maps of Europe, Clim Res. $2001 ; 18 ; 249-257$.

13. Olesen JE, Bindi M. Consequences of climate change for European agricultural productivity, land use and policy. European Journal of Agronomy. 2002;16(4),239-262. 